\title{
The Origins and Nature of the Greek City-State and its Significance for World Settlement History
}

\author{
John BINTLIFF \\ Durham University
}

Even today, most ancient historians and classical archaeologists, when investigating the origins and nature of the Greek city-state or Polis, are diverted from a clear perspective of the phenomenon by the abundant historical and archaeological data available for ancient Athens and Attica. Yet at the same time, the same scholars generally feel it necessary to remind us how abnormal and exceptional the Athenian Classical Polis is - probably from as early as the precocious union of Attica during the late Dark Ages.

Although, therefore, I find my colleague Ian Morris's radical reanalysis of Athenian society during the Dark Ages (Morris 1987) very convincing, I shall be deliberately provocative in arguing that the subtitle of his remarkable book Burial and Society, namely The Rise of the Greek City-State, is misleading, since the book's focus on Athens deprives the reader of the appropriate viewpoint from which to comprehend the true nature of the typical Greek Polis.

Throughout the 1980 s and 1990 s there have been many occasions when it has seemed that English-speaking scholars have been setting the pace in Classical Archaeology when it comes to fundamentally new and stimulating texts (one thinks of studies by Morris, Whitley, Osborne, Alcock). Yet these scholars are in reality operating within a narrow discourse focussing on the pathfinding research publications of their supervisor Anthony Snodgrass; it is a well-known phenomenon in Cambridge intellectual history that such fruitful but introspective schools can find themselves out-oftouch with developments in other scholarly traditions. One such, neglected, tradition is that of German historical geography of the ancient world, or "antike Landeskunde", and it is from this source that I shall draw fundamental inspiration for the following analysis.

Let us begin with my friend Eberhard Ruschenbusch, who in a series of penetrating studies (e.g.
Ruschenbusch 1985,1991$)$ has synthesized what we can say about the typical characteristics of the 700-800 known city-states of the Classical Aegean world. He has shown that: $80 \%$ of poleis studied have maximal territories of $100 \mathrm{~km}^{2}$ and citizen males around 800 in number, whilst $69 \%$ of poleis have only on average 400 adult male citizens - bringing total city-state populations (excluding slaves and resident aliens) to something of the order of 16003200 people. Now a "chora" or territory of $100 \mathrm{~km}^{2}$ maximal is equivalent to a radial territory of $5-6 \mathrm{~km}$ - and with this geographical and demographic scale before us we can focus realistically on what Ruschenbusch and others have termed the "Normalpolis".

The implications of such a small unit of space and population for a typical Polis were already brought out for us much earlier, in the works of another neglected scholar in the German antike Landeskunde tradition - Ernst Kirsten, most decisively in his major monograph of 1956 Die Griechische Polis (Kirsten 1956) with its significant subtitle als historisch-geographisches Problem des Mittelmeerraumes. The stimulus to Kirsten's researches on the Polis go even further back within the same tradition - to a question innocently raised by his teacher Alfred Philippson of Griechische Landschaften fame: "Why were there so many poleis in Thessaly?"

What indeed was it about this observation that gave rise to Kirsten's massive and brilliant monograph?

Now a tradition still purveyed today in ancient history textbooks informs us that Greece is made up of little pockets of plain, surrounded by sea and mountains and cut off from each other, hence determining the formation of miniature city-states. Thessaly - two linked, massive plains of fertile land, gives no cause for such processes - yet by Classical times it was crowded with such poleis (Auda et al. 1991).

In: Les princes de la Protohistoire et l'émergence de l'État. Actes de la table ronde internationale de Naples (1994). Naples, 1999 (Coll. CJB, 17/Coll. EFR, 252), 43-56. 


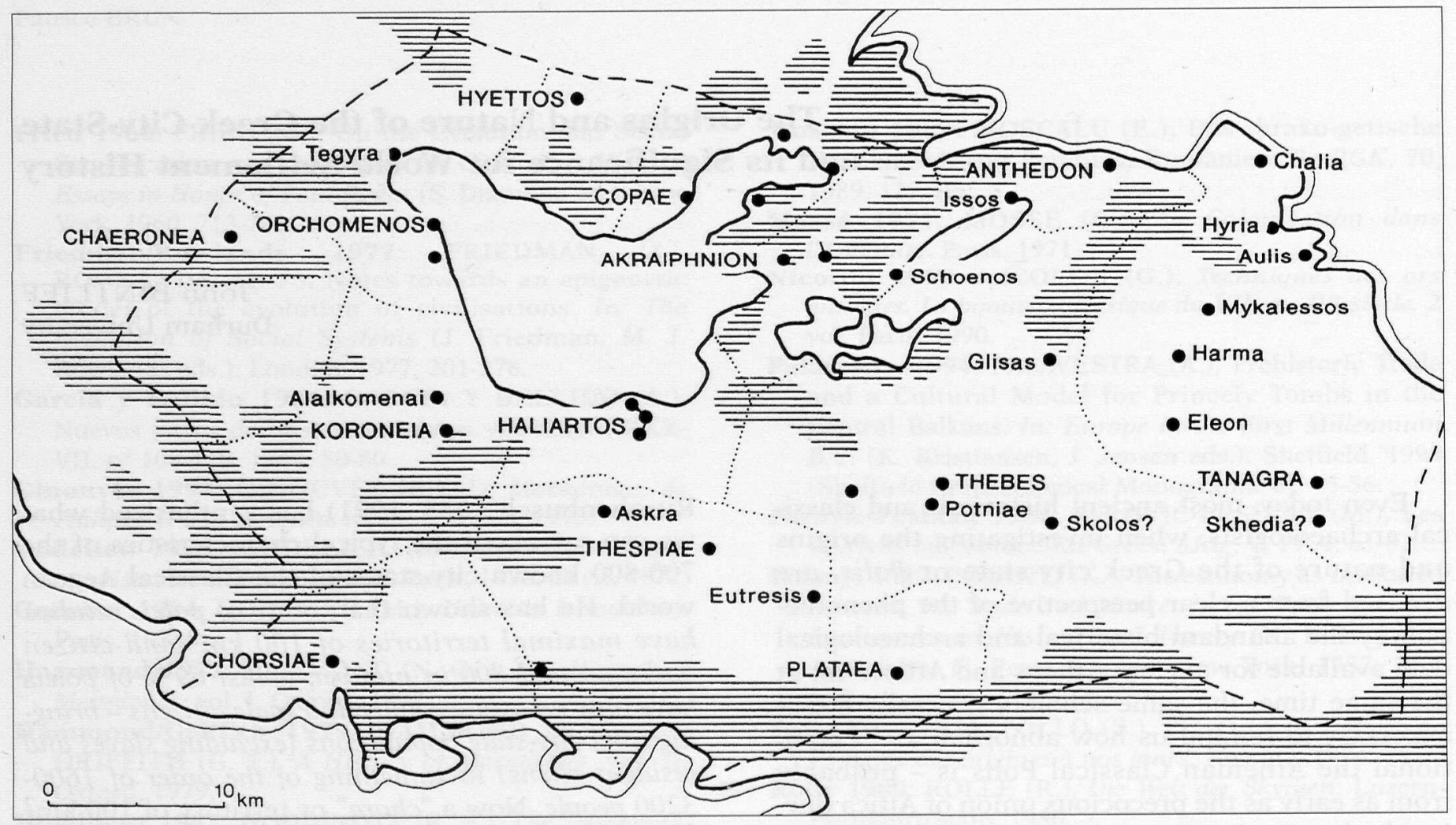

Fig. 1 - Distribution of Geometric sites in Boeotia. (Small rural sites are generally omitted).

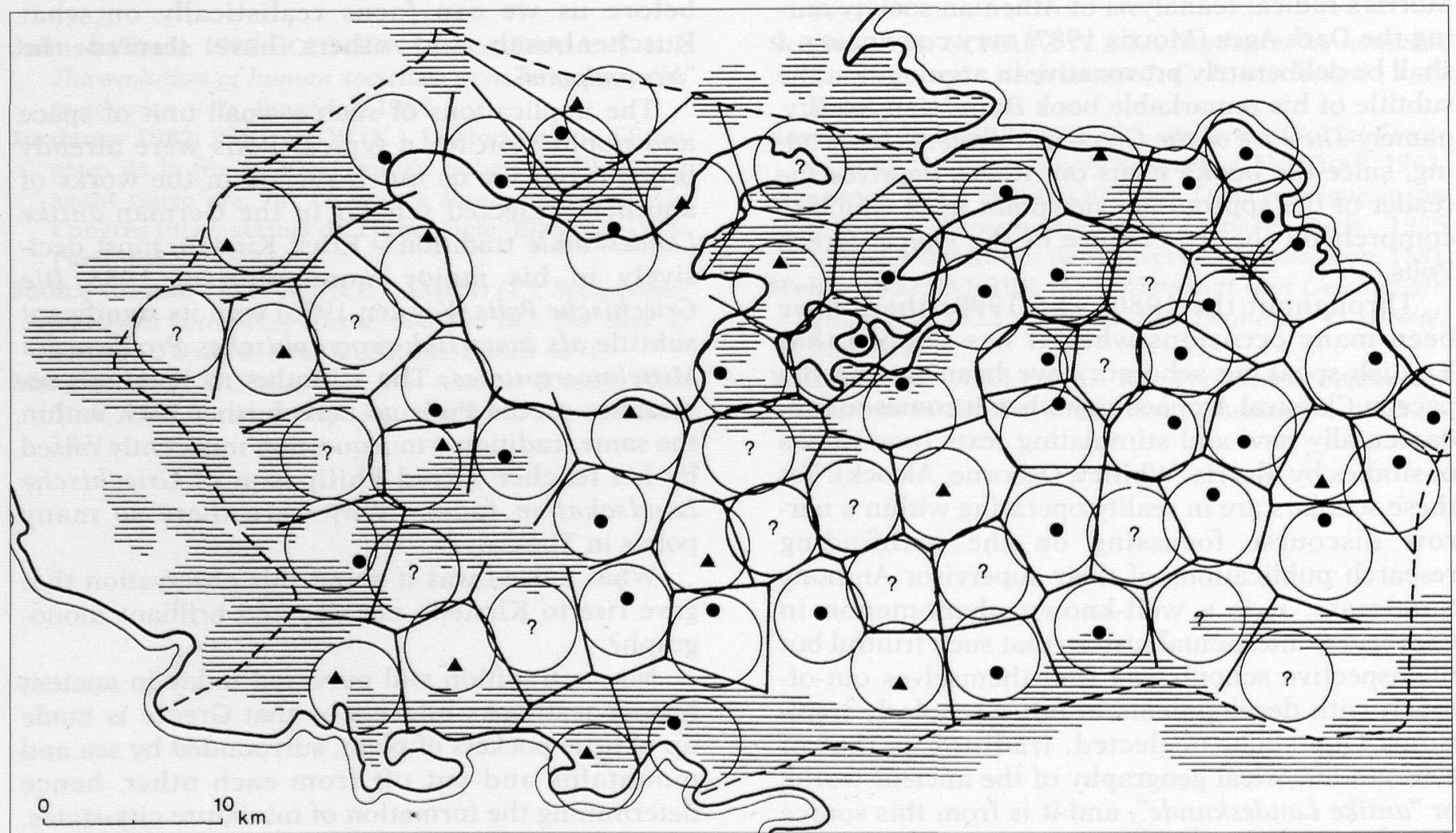

Fig. 2 - Town (polis- triangles) and village (kome-solid circles) communities in Classical Boeotia. Theoretical territories created through Thiessen-polygon analysis. Comparability of territorial modules tested through fitting a standard $2.5 \mathrm{~km}$ (half-hour) radius circle within them. Question-marks denote unoccupied landscape where the archaeology is little known and traditional villages exist, pointing to potential ancient village-sites. 


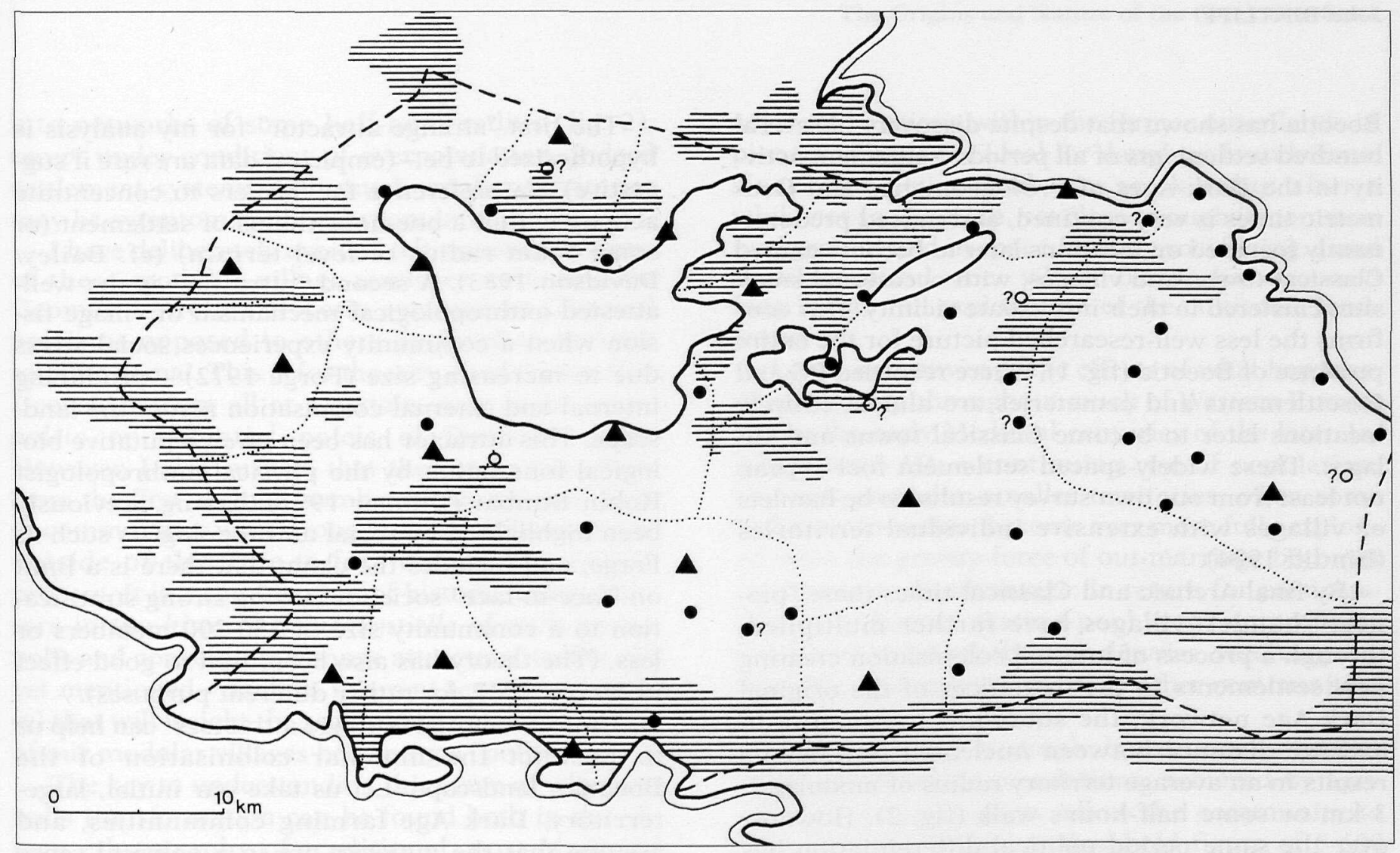

Fig. 3 - Enlarged territories of C 4th BC Boeotian dominant cities and territories of surviving small cities.

Kirsten's definitive solution to the problem is the touchstone for subsequent Landeskunde scholarship. Ignoring the smokescreen of legalistic definitions of the polis-state, he sees the phenomenon as a geographer: the typical Greek city-state is in reality a village - a large village - but essentially a village, with its integral agricultural territory, and the Normalpolis is in origin a Dorfstadt / Dorfstaat. Kirsten set aside for separate investigation the rare and abnormal development of much larger citystates such as Athens, which he compared to Medieval towns and called Stadtstadt/Stadtstaat and Megalopolis. I shall return to the latter category later.

I cannot more clearly show you the clarity of the Dorfstadt insight than through the example of modern Kastro village in Boeotia, Central Greece, which -neatly overlies the typical small city of Kopai and hints at a polis-village continuity even into the modern period, since its medieval occupants were an isolated pocket of Greeks amidst massive Albanian colonisation. However, since its medieval name - Topolia - is Slav, there should have been a strong influx of non-Greeks in early medieval times! Likewise little Chorsiai polis in S. W. Boeotia, studied by my friend John Fossey (Fossey/Morin 1987), with its compact small territory, has been replaced at no great distance by another surviving Greek community at the Byzantine to modern village of Chostiyani/Chostia.

Living every summer for almost two decades, as I have done, in rural Boeotia, where traditional villages are regularly spaced about the landscape in comparable scale to Ruschenbusch's territories, and with populations likewise of 1-3000 people, also brings home the "village" reality of Normalpolis life. In 1879 even the two "towns" of the Boeotian province had only 5000 souls each, making them only marginally urban rather than "very fat villages" with special functions (Sauerwein 1991). The fact, however, that over 100 years ago there were far more villages in the Boeotian countryside than today, and of smaller size and territory, stimulates us to search likewise for a dynamic development in early historic times underlying the mature form of Kirsten and Ruschenbusch's Dorfstadt/Normalpolis.

Boeotia offers a useful database for this "origin of the polis" analysis (Bintliff 1994), as a by-product of the Boeotia Project's continuing archaeologi$\mathrm{cal}$ investigation into its regional settlement history (a Project sponsored by the British Academy and directed by myself and Anthony Snodgrass). Our intensive surface survey both in S. W. and N. E. 
Boeotia has shown that despite discovery of several hundred settlements of all periods, settlement activity in the Dark Ages of Protogeometric and Geometric times is very confined, and indeed predominantly focussed on locations later to become named Classical towns and villages, with occasional small sites clustered in their immediate vicinity. This confirms the less well-researched picture for the entire province of Boeotia (fig. 1), where recorded PG and $G$ settlements and cemeteries are almost entirely locations later to become Classical towns and villages. These widely-spaced settlement foci appear, not least from our own survey results, to be hamlets or villages with extensive individual territories (Bintliff 1994).

By final Archaic and Classical times these "pioneer" hamlet/villages have further multiplied, through a process of internal colonisation creating new settlements in the interstices of the original Dark Age network; the subsequent reduction in average distance between nucleated settlements results in an average territory radius of modular 2$3 \mathrm{~km}$ or some half-hour's walk (fig. 2). However over the same period political differentiation has separated the modular nuclear foci into three classes: of "polis" - large and small - and dependent villages or komai. The territory of the poleis, which now incorporates that of their dependencies (komai alone for small poleis, komai and small poleis for large poleis), is larger, ranging from 5 to 10 or even $15 \mathrm{~km}$ radius with the variable power of individual city-states (fig. 3). Nonetheless - and this is the critical element - underneath the territorial radius of the larger and smaller poleis the fundamental settlement and territory unit remains that of the "village" territory originally specific to each polis and that of each of its satellite villages, whilst citizenship at both levels of the hierarchy rests upon landownership in the relevant community lands or chora.

I think it most helpful to see the modular infill of essentially large and small farming villages in Late Geometric to Archaic Boeotia as a human ecological process, influenced by Strange Attractors. I find it highly appropriate to introduce Complexity Theory into my argument at this point (Lewin 1993). This is an interdisciplinary body of ideas in the Biological and Physical Sciences which focusses on the tendency for complex systems with strong random oscillatory tendencies to converge on recurrent, semi-stable configurations or structures (Strange Attractors) through processes such as adaptive advantage, functional resonance, etc.
The first "strange attractor" for my analysis is hypothesized to be - (empirical data are rare if suggestive) - a preference for farmers to concentrate activity within a one-hour radius of settlement (or some $5 \mathrm{~km}$ radius of level terrain) (cf. Bailey/ Davidson 1983). A second "attractor" is the wellattested anthropological mechanism of village fission when a community experiences social stress due to increasing size (Forge 1972) - producing internal and external colonisation across the landscape. This attractor has been given a putative biological foundation by the physical anthropologist Robin Dunbar (Dunbar 1992), having previously been highlighted by social anthropologists such as Forge, and includes the claim that there is a limit on "face-to-face" societies lacking strong stratification to a community size of $150-200$ members or less. (The theory has also been used to good effect in Morris 1987, for rather different purposes).

These two initial "strange attractors" can help us to postdict the modular colonisation of the Boeotian landscape. Let us take our initial, largeterritory, Dark Age farming communities, and assume that the majority are in a political sense weakly-differentiated village/hamlet societies. Once these had risen in population above the hypothesized threshold for face-to-face social cohesion, they would split and cause colonisation of intervening land. Given Kent Flannery's important discovery (Flannery 1976) in early farming Mesoamerica that this stage of fission long precedes land exhaustion around pioneer hamlets, we might expect also for Boeotia that social factors dominated over economic, and that land use was still at a small percentage of available cultivable land when village fission occurred. Indeed the archaeological and historical evidence, together with the later development of intense land use, confirms the model for Central Greece. In such circumstances offshoot hamlets carved out territory from the outer parts of their parent's "parish" without threat to parental subsistence; if one sees this from the perspective of spatial geometry, a pioneer "maximal" territory of $5 \mathrm{~km}$ radius, after two phases of settlement fission and associated halving of territory on each occasion, would be reduced to a territory of $2-3 \mathrm{~km}$ radius. I would argue that further territorial subdivision, in dry-farming landscapes and with sizeable villages, would be a dangerous strategy, removing any economic cushion against resource fluctuations; this predicts a cross-cultural regularity - a third "Strange Attractor" - of stabilisation of mature dry-farming settlement systems 
into networks of some half-hour radius (fig. 2), except under conditions of overpopulation. Indeed settlement systems with much smaller territories may be symptomatic of overpopulation.

I have deliberately avoided telling you how some of these modular village-territory units of Late Geometric-Archaic Boeotia emerged as Classical poleis as opposed to others destined to become satellite komai. This is for the very good reason that I consider them all at a certain stage to be protopoleis or potential poleis of Dorfstaat type. However, I also suspect that there may have been from the first, a small number of exceptional, larger communities with strong political differentiation outside of this face-to-face community fission process. It is a combination of historic, unique factors in the histoire événementielle of each protopolis and converging "strange attractors" (some not yet mentioned - such as inherent territorial fertility) that will weight the scales for or against any one of our modular villages becoming a "polis".

The key to understanding this stage of village to polis transformation can be found both in the village ethnography of traditional, post-Medieval Europe, and in the insights of historians studying the development of early Medieval villages in Western Europe. Both research communities have, independently, presented similar models for transformation phenomena in village development. It will also help us to introduce yet another Strange Attractor unknown to these research communities: the prehistorian Martin Wobst's argument (Wobst $1974,1976)$ that healthy human populations require marriage/mating networks of 5-600 people to be viable in the long-term. I shall briefly attempt, using these insights, to reconstruct the main lines of village development in Medieval and postMedieval Western Europe of relevance to us.

Let us begin by taking the simplest form of village colonisation, such as may have been common in post-Roman Dark Age Europe: small, weakly socially-differentiated villages / hamlets of less than 200 people undergo regular fission due to social tension, and colonise interstitial land, with a resultant subdivision of original large territories. The "strange attractor" of face-to-face social relations has been operative (consider the eleventh century English Domesday Book village databank for an excellent confirmation ${ }^{1}$ ), but our modular villages, being too small for an endogamous marriage network, are necessarily being drawn through Wobst's attractor into cross-community intermarriage, to satisfy prohibitions on close-kin marriage. Thus adjacent locations within the former outer lands of pioneer villages are ideal for daughter foundations, since your new neighbours are kin, but after a while not so close-kin, yet close enough in common background and in space for easy socializing. Land is still plentiful since village fission has occurred long before full exploitation of the cultivable landscape.

Let us now envisage the effects of what happens, demonstrably, throughout much of Western Europe across the early Medieval centuries of the later 1st millennium AD: a continuing rise of population. Our new modular, smaller territories, often some half-hour in radius, become ever more fully exploited. Now the gravity-force of out-marriage becomes an economic disadvantage; in return for participation in a district mating-pool, your community loses land and stock through dowries, receiving distant plots and grazing-rights in other communities territory.

The resolution is simple but dramatic: further increases in village populations, achieved by agricultural intensification, allow the community to rise above the Wobstian threshold figure of 5-600 people and therefore to be largely endogamous; and the leaking of its life-blood, its territorial resources, shrinks to a trickle.

In a fascinating anthropological analysis Susan Tax Freeman (Freeman 1968, 1970) has shown how traditional Early Modern village Spain was dominated by large villages which had succeeded in this goal of territorial integrity and dominant endogamy - the "pueblo" village-town; alongside these idealized communities there existed smaller villages that openly acknowledged the disadvantages of their failure. Information on rural endogamy/ exogamy in Early Medieval Europe is less easily extractable in comparison to recent village Europe, but by the High Middle Ages when average village territories in lowland England and France, for example, were $1-3 \mathrm{~km}$ radius, and populations were frequently of appropriate size for a high level of endogamy, we might reasonably argue for processes comparable to those typical for Early Modern Spain and Italy with high levels of endogamy.

1 The detailed census of England commissioned by the Normans in 1086, the Domesday Book, lists some 13,400 villages. What is remarkable about the available statistics is that average village populations in each region are all below c. 160 people (Hallam 1981). The leading factor is likely to be village fission at the upper limit of face-to-face societies. 
But Freeman also underlines the importance of socio-political changes in the village as its resources come under pressure from internal population growth. Her emphasis on the "corporate community" is echoed independently by medieval economic historians such as Harold Fox (Fox 1981, 1992) who has focussed on the problems arising from continual population increase within the dense network of early Medieval rural communities across the West European lowlands. Arable, and more particularly pasturage for farm and ploughstock became in critical short supply. Although by around $1100 \mathrm{AD}$ the absolute number and spatial network of villages was largely in place, the result in many regions of colonising villages trying to stabilise at face-to-face level, between $1000 \mathrm{AD}$ and $1250 \mathrm{AD}$ most European villages continued to grow internally, doubling or tripling population from their original size. This may have relieved land pressure in one respect, through minimizing of out-marriages and maximizing resource negentropy, but it greatly increased the stress on internal land use. The solution found was the one that is also a characteristic of large traditional villages in Early Modern Europe: the creation of a "corporate community" 2 .

This was a unified body, usually consisting of the wealthier adult male landowning heads of households, which assumed complete control over the entire village territory, reassigning land where necessary and generally assuming management responsibility over the resources of the village. A remarkable specific achievement of these Medieval West European village councils appears to have been a decision, which once taken spread rapidly throughout lowland West Europe, to confront pressure on the village arable and grazing territory through a complete root-and-stock restructuring of land use. The haphazard accumulation of individual family plots and pasturage was abolished and a new scheme was pushed through in which 2-3 giant fields were laid out and used in strict rotation by all villagers for similar annual land usage.

Students of the ancient Greek Polis will I am sure have begun to recognize from far off some key features, perhaps the key features of Classical citystate life, in these Medieval and post-Medieval West European village developmental trajectories: the identity between closure of territorial integrity and a strong political community with its roots in landholding within the territory; the necessity of endogamy for almost all polis citizens, since non polisborn residents cannot own land and are therefore de facto excluded from citizenship, landholding being the principal qualification for full membership of the political community. As an intriguing footnote to the fashion in which polis-exclusivety extended itself into all essential areas of community life, foreigners (i.e. non-citizens) in Greek poleis were only allowed to participate in polis cults through the medium of a citizen intermediary or "proxenos"; this even persisted in "interstate" sanctuaries such as Delphi, where citizens of Delphi had to act as continual intermediaries for pilgrims (SourvinouInwood 1990).

If you like, the Greek polis, the Spanish pueblo, the High Medieval West European village, have "squared the circle": most of them will have begun life as "face-to-face", fissioning and colonising hamlets gradually filling the landscape in modular patterns, pulled towards the strange attractors of social and ergonomic space. Colonisation of neighbouring sectors of landscape through territorial geometric subdivision was also in part a response to the pull of mating network requirements. Subsequent continuing expansion of population and intensification of land use placed growing stress on the territorial integrity of each community's resource space, a tension which was resolved both naturally, through increasing closure of an endogamous marriage pattern, and artificially, through the establishment of a powerful council of the chief landholders with the power to intervene in questions of land use within the community's territory. The central achievement of these recurrent settlement forms is that the mating community circulates, within the "chora", its resources - human and environmental.

In essence we have created the DorfstadtDorfstaat, and if our analysis is correct we cannot conceivably view the Greek Polis as a unique phenomenon, just because it has special features such as its own army, or claims complete political autonomy, and carves absolute laws on its walls: one could argue that the Medieval Three-field system is just as remarkable a community achievement.

Yet I perhaps deliberately overstate the case, to prevent a chauvinistic blinkering amongst Classicists. Nonetheless, there are fundamental parallels

\footnotetext{
2 Ian Morris (Morris 1987, 5) also notes parallels between the "corporate community" of anthropological theory and the Greek polis, but does not pursue the analogy into the human geographic and biological dimension as we wish to do here.
} 
in the processes I have described, and they are largely the product of the same "strange attractors". What is it indeed that prevents the Spanish pueblo or the High Medieval village of say, Northern France from "U. D. I."? It is the fact that they have developed under the restrictive political superstructure of the Iberian kingdoms and lordships, of the French feudal kings, barons and knights - albeit with extensive local powers vested in the corporate communities of the village councils, especially in the realm of territorial management. What I would claim is bold enough: that in the absence of such prior authority, or in cases of weak expression of higher powers, the same strange attractors will begin to produce similar results to Greek polis formation. Symptoms can be seen in post-Medieval Italian hill villages waging war on each other (Tak 1990), or more recently terming themselves "villages by day, towns by night". For a full realization of "polis" potential, we might turn to the rise of the genuinely autonomous Italian city-states of the Middle Ages - arising predictably in a regional power-vaccuum within North-Central Italy; or for a much earlier era, we could focus on the multiple small city-states of the Bronze Age in the East Mediterranean.

Ruschenbusch's statistical survey and examples I have cited from Boeotia make it clear that the vast majority of Dorfstädte or "village-poleis" remained in scale as large villages. Some such as Chorsiai or Kopai survived as single settlement, $2-3 \mathrm{~km}$ radius territory cities of "proto-polis" type, at the lower end of, or even below, Ruschenbusch's average population figures, throughout Antiquity. But a typical 5-6 $\mathrm{km}$ radius territory polis, at the upper end of his average size scale (towards 3000 or more people) will generally have reached these spatial and demographic dimensions by enlarging its chora through absorption of one or more neighbouring "proto-poleis".

Thus in S. W. Boeotia, Askra village, already by Hesiod's time, at the dawn of the Archaic era, appears to be a satellite of $5 \mathrm{~km}$-distant Thespiae. Plausibly at an earlier stage Askra may have been autonomous, and if some ancient sources can be accepted, during the Archaic era hostilities led to a Thespian expulsion of the Askraeans and a resettlement of the kome/village (Snodgrass 1990: a possible fortification of Archaic-early Classical style might relate to this episode).

Boeotian history, indeed, from the start seems characterised by "polis predation", whereby over time those proto-poleis which emerge as true poleis do so either by survival in remote corners of the province, or more normally by increasing their regional power through incorporation of neighbours into their territorial states. The Normalpolis, therefore, at the medium to upper end of its scale, although it can be a single large settlement with a maximal farming catchment of $5-6 \mathrm{~km}$ radius, is much more likely to represent a larger community together with subordinate proto-poleis and their lands. The pretensions and/or fears of all protopoleis during the Archaic era of polis predation seem to be reflected by the widespread practice of community fortification during this period for all communities beyond the hamlet.

The organizers of this Colloquium have admirably posed questions of importance to my analysis, one of which I shall pause to consider: is the dynamic of State development linear - or even "NeoEvolutionary linear"?

In espousing Chaos-Complexity theory I am arguing for a certain timelessness, a certain semideterministic set of processes "waiting to act"; yet there are parameters with chronological meaning which affect the likelihood and scope of operation of the relevant strange attractors which I have sought to identify in Greek settlement history and elsewhere.

The predominance of fixed, nucleated settlement is to be associated with settled village farming; the ability to produce sufficient food to enable a village to become demographically stable in virtual Wobstian endogamy is a feature especially to be, associated with additional factors - such as Mediterranean polyculture (relevant as early as the Bronze Age in the Levant and Southern Greece), or effective iron technology (relevant to early historic Greece and Italy), or social modifications such as the Medieval Three-field management system. Power vaccua, or weak overarching power-structures, however, once regional state systems are in existence in a particular part of the world, can occur at more arbitrary times, and hence within the agro-techno constraints already noted the corporate community and the Dorfstaat can appear in many different localities, cultures and eras - without prediction, but open to postdiction (to borrow a noteworthy concept of Stephen Jay Gould's [Gould 1986]).

To return to the dynamics of polis-formation in ancient Greece: whether or not one is tempted to extend a biological analogy to erect an hypothetical strange attractor of territorial predation, it is an empirical fact that, progressively, most of the 2-3 


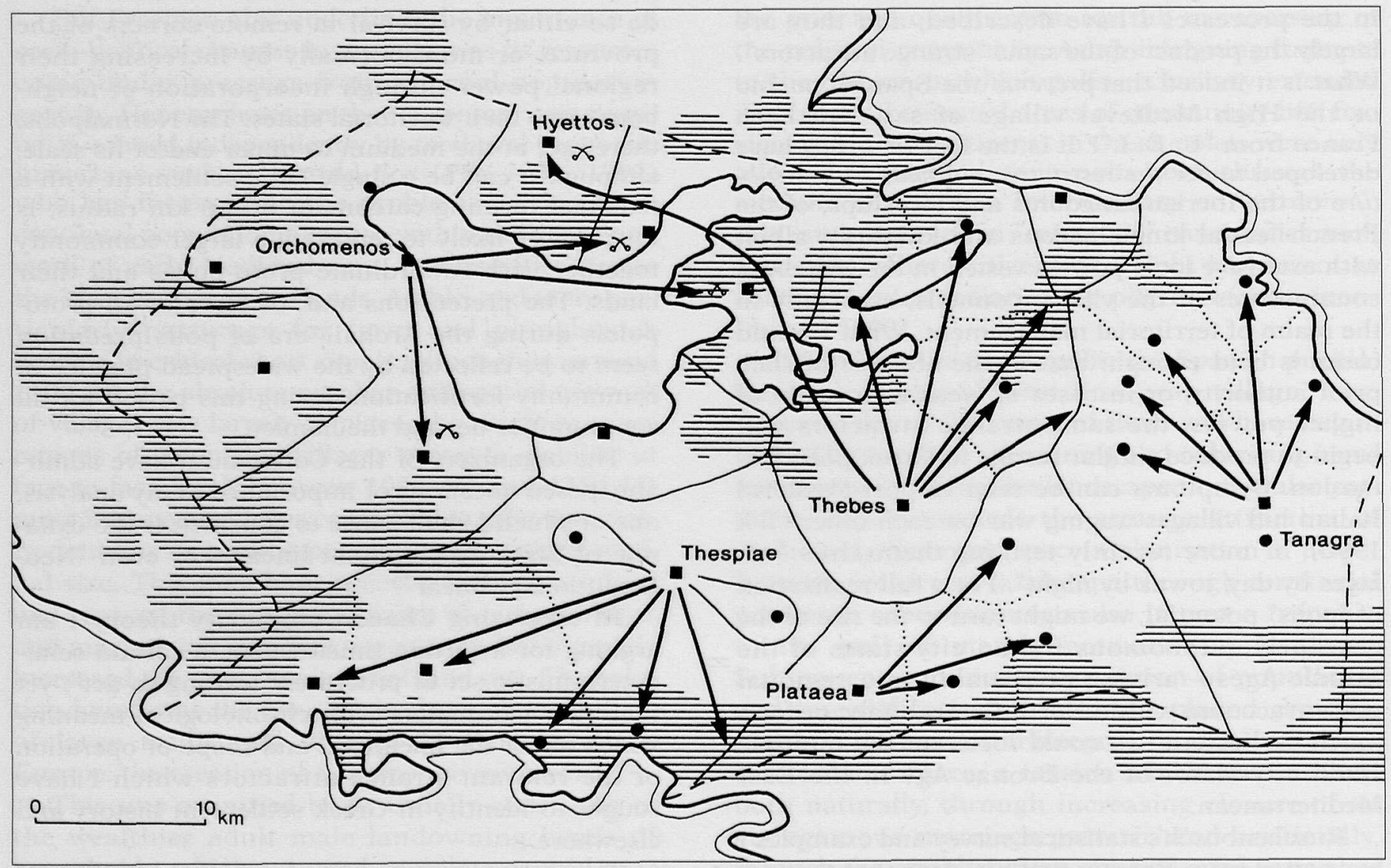

Fig. 4 - The process of 6 th Century BC absorption of minor towns and villages by dominant towns in Boeotia.

$\mathrm{km}$ radius proto-poleis are absorbed over time into the territories of larger poleis in the course of the Archaic centuries (fig. 4) if not in final Geometric times. Thus in Boeotia, most proto-poleis lose their independence and there remain only 14-15 truly, or semi-autonomous poleis for the province in mature Classical times. These survivors are nonetheless regularly at odds with one another, and are also all threatened by the giant community of Thebes. Dominating local politics through most of the C5th $\mathrm{BC}$, Thebes succeeds to total control over Boeotia and then to hegemony over Southern Greece during the early C4th BC; subsequently the other cities manage to reassert themselves, and most continue as political entities, with diminishing powers, till the end of Antiquity - when they, often already shrunken to proto-polis size again, become transformed into Medieval villages.

I have yet to say something about "Princes" or indeed about social hierarchy. The time has come! I shall do so through the intermediary of further intriguing details in the Boeotian polis development sequence.
From the earliest clear archaeological evidence in our survey areas of S. W. and N. E. Boeotia, the "pioneer" Geometric villages show quite disproportionate sizes (Bintliff 1994): Askra is a small, tightly-focussed hamlet and will become a large kome/ village under Thespian control by Archaic times (perhaps after its polis pretensions are thwarted); Hyettos has a reasonably extensive area, perhaps in the form of several close hamlets, in Geometricearly Archaic times, and will become a middlerange autonomous polis; Haliartos appears to be yet larger in its formative phases, but a single extensive community - it will grow into a middleto-large polis; finally Thespiae has a number of hamlet foci over a wide area and will become one of the larger poleis of Boeotia. It seems as if their future Classical status is already anticipated in the size of these villages in the final Dark Age to early Archaic era. That hypothesis receives confirmation if we turn to consider the case of Thebes: it has very widely-scattered multiple hamlet foci in ProtoGeometric and Geometric times, that seem to point to an exceptionally large community, appropriate 
in scale to its remarkable pre-eminence in size throughout the Classical era.

We can therefore suggest that the "dice are loaded" when it comes to proto-polis interactions. Even though Askra will achieve (with a putative 1300 or so inhabitants and a discrete $2-3 \mathrm{~km}$ radius fertile territory), potential polis integrity by Classical times if not earlier - already by the commencement of the Archaic era, two centuries before, we have Hesiod to inform us that power lies with the corrupt chiefs or basileis in "the city" of Thespiae and not with the occupants of his "village". So the basileis - the local aristocrats, are present, at least in a dominant, newly-emerged, larger Dorfstadt. This leads rather naturally onto the next very significant question: what then, does this make Hesiod, politically?

Social theory, and now biological theory, argue that communities which rise above the face-to-face mode of social integration require either, or both, horizontal or vertical stratification. Some subdivision of the community into separate quarters (barrios) or kin groups, or the emergence of a group of powerful individuals (Big Men), even the stabilisation of a class of powerful versus a class of subordinate families - these are characteristic phenomena associated with the social infrastructure of large communities.

We can surely see in the archaeological evidence for multiple foci of burial and occupation in the medium-to-large emergent village-poleis of Dark Age to early Archaic times, such as at Thespiae, Hyettos, and Thebes, as at Athens, Argos, and equally in the comparable phase of city emergence of Etruscan cities - the direct reflection of distinct social groups predicted by these general theories. As well as this evidence from which to infer a horizontal infrastructure, we can reintroduce Ian Morris's interpretation of Dark Age Athenian cemeteries (Morris 1987), which has won unqualified support in claiming that a vertically-stratified society dominated life throughout the main part of the Attic Dark Ages: not only are cemeteries revealing high-status and lower-status families, but it is suggested that consistently only $1 / 3$ to $1 / 2$ of the adults of the community are receiving formal burial (the Agathoi), concealing a hidden lowest class (the Kakoi) ${ }^{3}$. We can therefore recognize a three-level social hierarchy.

This persistent inequality, of course, puts into helpful context the otherwise remarkable Lefkandi elite (house and?) tomb from early in the Greek Dark Age ${ }^{4}$, and the clear literary evidence from the final Geometric era at Askra/Thespiae for three levels of status in Hesiod's society (with upper class basileis, yeoman farmers such as Hesiod with dependents, and free/unfree dependents together with the poorer villagers). James Whitley (Whitley 1991) has argued that the dominant families comprising the uppermost stratum of the upper class (Agathoi) were unstable Big Men, citing the role of hero-cults, archaising art, and false genealogies in early historic Greece as evidence for an absence of genuine aristocratic stability; social mobility between the upper and lower divisions of the Agathoi is therefore envisaged.

I return to the question: Who then is Hesiod, in social terms? Most commentators place him firmly in the class of wealthier farmer, chafing at the power of noble families in Thespiae. The Hesiodic "yeoman farmer" class is recognized to be a critical force in the rise of the polis, because over the Archaic period, (despite continuing debate over the precise details), it is generally agreed that a fundamentally new military and political factor established itself in all poleis - that of the heavily-armed citizen footsoldier army in an organized formation or phalanx.

This vital defensive and offensive arm of the polis is essentially composed of "middle-class" farmers with surplus wealth sufficient to maintain the heavy armour and weaponry of their "hoplite" class. Aristocrats, although still the primary source

\footnotetext{
3 The average group being buried in separate plots within major Attic cemeteries throughout the period Proto-Geometric to Middle Geometric is merely 1-2 adults, interpreted by Morris as family heads of an upper class; if we add sub-adults we obtain a family of 4 . Before and after this long era of status exclusion (i.e. in Submycenaean and Late Geometric times), burial plots appear to expand to include an additional 2-8 burying individuals of a lower class, as well as more subadults. Morris therefore generalizes to suggest that the ratio upper to lower class is of the order of $1 / 3$ to $1 / 2$ of the total population.

${ }^{4}$ David Ridgway's discussion of the significance of Lefkandi for local and Mediterranean-wide society (Ridgway 1992), is, I think, the most helpful yet to appear. He envisages Lefkandi as a smallscale participant in a growing trade system in which Levantine traders were dominant. Benefitting from an awareness thus engendered of commercial and other economic opportunities abroad, and suffering from the crisis of the Lelantine War, the Euboean communities, in his view, undertook a colonisation to a new environment - hence the early Euboean settlements of Central Italy (these are traditionally founded by the neighbours of Lefkandi - Chalcis and Eretria - after the former's decline).
} 
of an accompanying cavalry, are in time not ashamed to stand anonymously in the hoplite formation. The military superiority of the new citizen army is such that it rapidly displaces other traditional forms of land warfare in the polis landscapes, and it has rightly been stressed that political powersharing between the hoplite class and the aristocracy was both advantageous to polis security and a pragmatic necessity. The archaeological shift from weapon burial in tombs to its cessation in favour of dedication of the same items in "public" polis sanctuaries, (a strong contrast between the Late Geometric and the succeeding Archaic era), has also been seen as marking the military cohesion of the new polis-state, as it broadens political participation to the yeoman / hoplite class. Anthony Snodgrass has recently suggested (Snodgrass 1991) that the Polis is generally emerging in Southern Greece between the late C8th and the early C7th $\mathrm{BC}$, with the hoplite phalanx in widespread use as an a posteriori proof of polis existence between 700$650 \mathrm{BC}$

Hesiod should then be seen as a member of a class which, it would seem, after his time, will use its growing economic prosperity to equip itself with appropriate military gear and obtain power-sharing in the polis-state, as the hoplite class. At the same time he is clearly in a distinct social stratum from a class lower than his which includes hired-labour and slaves.

Now here is a paradox: whilst Ian Morris convincingly documents that $1 / 3$ to $1 / 2$ of Dark Age society, at least in the larger settlements, may be taken to represent a generalized upper class (the Agathoi), with the remainder belonging to a lower class (the Kakoi), he fails to observe the resonance that these proportions evoke. The reason, once more, I suspect, is the Atheno-centric bias of his study, where the future development of the polisstate is towards an extreme experiment in democracy encompassing all of the Kakoi and the Agathoi.

In the Other Greece, the Greece of the 7-800 "Normalpoleis", however, the typical political constitution by Classical times was just as likely to be that of a very broad oligarchy for all or most of Antiquity. Boeotia is a good example. Citizenship came for all free-born of citizen-parents within the state-territory, but political power was restricted to those male family-heads with a minimum propertystatus - almost always limited to the hoplite class and above. Now as is well-known, and here the numerical resonance occurs, the hoplite-hippeis (noble) class together comprised, on average, 1/3 to
$1 / 2$ of the citizen population in a typical Greek polis (cf. Snodgrass 1991, 19).

The inevitable conclusion has to be, that in the development of the Normalpolis of ancient Greece, the crucial division of an upper class and inferior class, typified by the oligarchic constitution of all Archaic Greek city-states, and remaining typical for at least half of all Classical city-states (Prof. Peter Rhodes, pers. comm.), - already existed in the same proportions within Dark Age communities, at least in larger settlements such as at Athens. The Dark Age Agathoi included what will later be formalised as the hoplite class. Put this way, the generalized emergence of the Polis during early Archaic times is not the great democratic extension of political status to the lower class or Kakoi that will be the ultimate achievement of Athens in the C5th BC, and more subtle interpretations are called for.

Here a clue may lie in Snodgrass's recent (Snodgrass 1993) reanalysis of the origins of hoplite warfare. It does seem likely that in the later Dark Age at least, the posturing antics of the aristocratic warrior class were accompanied, not just by a rabble of ineffective and poorly-armed peasants, but by a more significant military force of "middling-status" folk - even though this has not yet formed into a coherent formation or phalanx. Gradually, from Late Geometric times into the C6th BC these protohoplites as a class become more fully-armed, more formation-armed and more formation-active, until the polis army is effectively the citizen body as a solid phalanx.

Adopting a gradualist position enables us to find more subtle shifts across the Dark Age to Archaic transition. Following Whitley's "unstable" nobility model, let us assume that the Dark Age communities of larger size (those of say five hundred or more), were composed of leading families associated with a class of prosperous yeoman-farmers (the "proto-hoplites") - both levels being permeable to two-way social mobility along Big Man principles, together with an equally, or more, numerous lower class. In warfare and economic rivalry the families of both upper-class levels may have witnessed cyclical fortune. We might mention in connection with this, Bill Cavanagh's (Cavanagh 1991) comment on the "genealogical shallowness" suggested by the short life of Dark Age tombs at Knossos, which he interprets as showing limited kinship links and a low degree of continuity in lineages of powerful families. Set apart, however, from the two-level upper class, whose adult members are privileged by formal burial, is a lower class of lesser folk, the 
Kakoi, dependent on the Agathoi both socially and economically.

We might hypothesize further, that although privileged in burial, and considered a useful fighting element in inter-community warfare, the "proto-hoplite" class has limited power or influence in "affairs of state" in the emergent Dorfstaat, even if far from being servile; it would comprise the fully autonomous and prosperous clients of the leading families, people whose allegiances could shift and be of some potency in the aristocratic politics of the pre-hoplite reform era.

Smaller communities, which I have earlier suggested to have been the most likely source of landscape infilling by village-fission, may well have lacked members of the uppermost class of basileus status, and even its prosperous peasants of the lower Agathoi class could have been subject to twoway mobility with other free-born Kakoi families in their communities - probably Hesiod's Askra was such a place.

At different times in different places across the early Archaic era, the growing numbers of prosperous "middle-class" farmers and their increasing military effectiveness, and the "scissors" created by the need for greater territorial integrity associated with heightened endogamy, stimulated the creation of the corporate, power-sharing community, the broad-based oligarchic polis, in which the hoplite voice was truly powerful ${ }^{5}$. Let us recall that even Athens only became a true citizen-democracy with the Kleisthenic reforms at the very end of the Archaic era. Such a transformation in the structure of power, driven on by demographic and economic trends, refocusses our attention on the very real modifications in the levels of human activity across the Greek landscape between earlier Dark Age and final Geometric to early Archaic times, which Ian Morris's revelation of the artificially-exaggerated rise in burial numbers across this transition has unintentionally served to obscure for the scholarly world.

It is surely not coincidental, that in the moderate oligarchy which typified the Archaic polis, and remained as common as a wider democracy in the Classical polis, a citizen population of average 1600 people (some $69 \%$ of Ruschenbusch's database) would imply a ruling hoplite-hippeis class of some 134-200 adult males - ideal for a face-to-face politics.

Finally some comments on the Abnormal Polis (Bintliff 1994; Kirsten 1956). In Boeotia, Thebes may have retained a large population and an elabo- rate social structure throughout the Dark Ages, and will sustain this lead in size through inter-community aggression through the final Geometric, Archaic and Classical periods, until achieving regional hegemony in practice during the $\mathrm{C} 5$ th $\mathrm{BC}$ and in official name during the early C4th BC. By its apogee its walled area may have been 350 ha,

\footnotetext{
5 The problem of accounting for the apparently late appearance of "primitive"-seeming social divisions in the early polis world - phylai (clans), phratries, and gene (extended families), could be rather speculatively resolvable as a late development of new organisational mechanisms out of the earlier less formal tripartite class structure just discussed. From the uppermost aristocratic class might emerge the smallest unit - the aristocratic genos, whilst the Agathoi as a whole, including protohoplites and leading families, might emerge into the large-scale phratry system, and lastly the incorporation of the lower class of free-citizen - the Kakoi, could account for the most inclusive organisation of the clans or phylai. Murray (Murray 1990) has already indicated that in his view the Phratry may have begun as an upper class warrior organisation under the control of a leading kin group or Genos. Funke (Funke 1993) also seems to be hinting at such a viewpoint, when he points out that these forms of infrastructure are so common in the Greek polis, and so similar from one state to another (e.g. the Ionian and Dorian poleis had 3-4 Phylai with recurrent names), that rather than being an ad hoc artifical solution to the growing complexity of the polisstate, these must reflect some underlying features of these societies. Ian Morris's curious omission of discussion of these intrapolis social forms may stem from his overconcern with a view of the polis as a monolithic democratic institution - which neither fits the oligarchic Normalpolis, nor indeed (cf. infra) the Archaic polis of Athens.

If Agathoi in the Dark Ages intermarried preferentially amongst their own class, the requisite social network of neighbouring communities participating in their gene-pool, except within the largest settlements, must have been rather large. This brings into sharper relief the possibility opened up by the strange attractor of community-size increase to above gene-pool thresholds, as a means of resolving the growing problem of retention of land resources within the community. As the hoplite-hippeis elite remained socially distinct in the Normalpolis world of Classical times, a continuation of preferential inter-elite marriage would call for a total community population of some $1000-1200$ people, if $1 / 3$ to $1 / 2$ were to form an adequate gene pool in itself. The Normalpolis of $1600-3200$ people clearly satisfies these requirements. Interestingly in this connection, Hedrick (Hedrick 1991) has suggested that Phratre formed an alternative unit of the early Athenian state before Kleisthenes refocussed it on the village-deme in the final C6th $\mathrm{BC}$; his examination of the phenomenon seems to point to multi-community, non-kin social networks with leading families (the Genos) at their head, which might well represent foci for Agathoi intermarriage across communities which preceded the growth of deme-villages to greater self-sufficiency in this respect.
} 


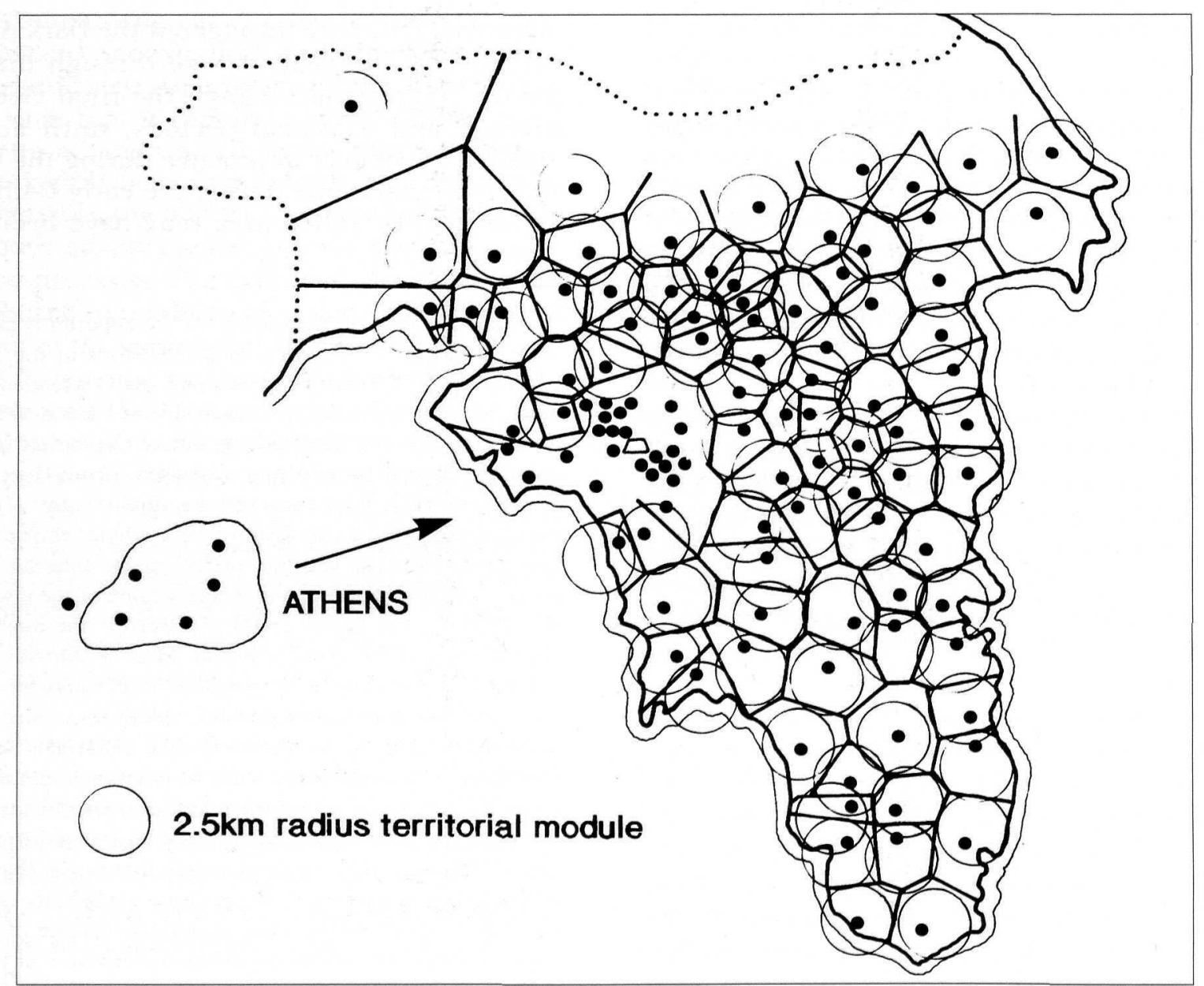

Fig. 5 - Thiessen-Polygon analysis of locatable deme-centres in Attica (rural) (after Traill 1975).

one-and-a-half times the walled area of C5th Athens (c. $211 \mathrm{ha})$, and one may suggest a population in Thebes itself of some $30-40,000$ people. It is truly on the scale of a major medieval city and exists in another class altogether from all other poleis in its province. As a Primate City its role has nothing to do with the Dorfstadt, and its economy and politics are on a far more grandeous level. It is, to use Ernst Kirsten's useful phrase - a Megalopolis, playing to a very different set of rules from its neighbouring poleis.

Nonetheless from the Dark Ages onwards it has had to fight its way across the landscape from a confined territory, absorbing or expelling adjacent populations in a process of relentless expansion. Its territory from the first appears to be larger than average, and this hints at a continued subordination of satellite hamlets from Bronze Age times, or a very early incorporation of its nearest neighbours. Yet the behaviour of the Theban Megalopolis goes well beyond the typical centre-plus-satellite system which larger Normalpoleis grow into: Thebes is known to have forcibly resettled some villages within its walls and expelled other competing settlements entirely from the region. This sharper version of predatory territorial expansion is reminiscent of Syracusan "ethnic cleansing" on Sicily (a Megalopolis of comparable size) (Berger 1991), and to my mind deserves further investigation, arguably from a socio-biological perspective.

Moving across the Boeotian frontier south, it is intriguing to re-examine the case of the rise of the Athenian Polis "from the bottom-up", since the Attic province is almost identical in size to the whole of Boeotia. Ian Morris's helpful synthesis allows us to suspect a similar process of landscape infilling to that seen in Boeotia during Dark Age to Archaic times. We would also follow Osborne (Osborne 1985) and Whitehead (Whitehead 1986) in concluding that the resultant dense network of Attic settlements is essentially a village network. In their view the Kleisthenic constitutional reforms of 
507-8 take as given the fact that the people of Attica live in some 139 rural villages or urban suburbs (demes), from which already existing units, a centralized political system for a unified single-city, Athenian state can be forged using such natural "building blocks" as constituencies.

A geographical analysis of the locatable demes (Bintliff 1994) suggests strongly that the rural districts of Attica have village territories of on average $2-3 \mathrm{~km}$ radius, just as in Boeotia, whereas the urban and "rural-suburban" (astu) demes are far more territorially-packed with an average 1-2 km radius parish ${ }^{6}$ (fig. 5). From the councillor quotas for 507-8 BC, which are believed to represent each village proportionate to population, we can also see that there are a series of very large "villages", or rather small towns, in Attica - Athens does not stand alone above a sea of small, rural hamlets 7 .

Let us recall that Athens is unusual in its precocious unification of a large province based on a single city, and that because this happened before recorded history - perhaps in the vigorous $\mathrm{C} 8$ th $\mathrm{BC}$ - we find it difficult to give proper credence to what then have to be classified as semi-legendary tales of events preceding unification. In particular we need to take more seriously those repeated stories of open rivalry between the nascent power of Athens and that of several alternative and autonomous centres of Dark Age power in Attica, out of which Athens alone emerged victorious. In our comparative perspective from Boeotia and the Normalpolis world of the Aegean, such a scenario seems all too reasonable - with a similar putative early structure of numerous proto-polis villages (the demes), some already unusually large and associated with highstatus burials (and some of these by 507-8 BC are appropriately of the size of a medium-to-large polis in other landscapes). The "demes" of Athens are not merely the reflection of the state or the "Demos" as Robin Osborne seems to suggest: the villagedeme is the basic building-block of the "polis" in "normal Greece" and will also have played a surprisingly important part in the formation of the Athenian state ${ }^{8}$.

6 The outer "inland and coast" demes of Attica have an average $2.53 \mathrm{~km}$ radius territory, those of the "city" region clustering around Athens a mere $1.72 \mathrm{~km}$. Is it purely coincidental that territorial division on an equal basis from a base of $5 \mathrm{~km}$ radius territories produces the following territory sizes with each generation of further subdivision: $3.5 \mathrm{~km}, 2.5 \mathrm{~km}, 1.8 \mathrm{~km}$ ?

7 Larger than average Attic demes in the late C6th BC include Acharnai with 22 councillors, Aphidna with 16, Lower
Paiania and Eleusis with 11, and Marathon with 10. If citizen numbers in the late C6th BC were as much as $75 \%$ of the 25 30,000 adult males commonly accepted for 480 BC (cf. Garnsey 1988), a total Attic citizen population at that time of some 84,000 people might be "guesstimated". 500 Bouleutes or councillors would each represent c. 168 citizens. This would imply that the larger "townships" in late Archaic rural Attica cited above had some 1700-3700 people, putting them into the scale of Ruschenbusch's Normalpolis. Even the typical village-deme, with 3 or more councillors, is likely to be a sizeable community of 500 or more citizens and therefore with the potential for a high degree of endogamy. The existence in some demes of shared councillors suggests that rounding off local population to a whole number of councillors, thus artificially raising apparent deme population, is unlikely.

${ }^{8}$ If the formation of the polis-state is fundamentally the full enfranchisement into a "corporate community" of moderate oligarchic type of an already privileged lower noble/agathos class the "proto-hoplites", then Ian Morris's "retreat" of the polis in Athens as evidenced by the reversion during Archaic times to privileged minority burial, cannot have the significance he attaches to it. The polis of Athens seems to have been already formed during the $\mathrm{C} 8$ th $\mathrm{BC}$ and its power-base was oligarchic if broad-based. Complete enfranchisement of the poorer free classes amongst the Kakoi occurred piecemeal, beginning with the Kleisthenic reforms at the end of the C6th BC and continuing with C5th BC legislation (as Morris acknowledges, 1987, 205 $s q$.) An increased status for the sub-hoplite class in burial terms is an irrelevance to a consideration of the politically-effective classes in contemporary Athens during the first two centuries of its life as a polis - the hippeis/aristocrats and the hoplites. Morris (Morris 1987, 184-186) unwittingly underlines the problem by noting how Argos and Corinth also see a broadening of burial privilege to reflect the new "citizen polis" in a comparable fashion to burial changes in $\mathrm{C} 8$ th $\mathrm{BC}$ Athens, yet here we have political milieux that will stabilise into hoplite-hippeis oligarchies.

A more fruitful path to comprehending the significance of the shifting status of the Kakoi, is to move away from seeing it as central to the creation of the polis at Athens or anywhere else, and consider it instead as a symptom of the malfunctioning of the oligarchic polis. Professor Albert Schachter (McGill University) has kindly shared with me (pers. comm.) his alternative interpretation of the "burial status retreat" at Athens, namely that it is a direct reflection of a social instability arising from the extreme poverty and indebtedness of the lower peasant class, a weakening of a particular productive class which called forth the drastic intervention of a reforming lawmaker in the person of Solon. The suffering class will be the free Kakoi who, although briefly included, then excluded, from formal burial privileges during the Archaic period, are never fully enfranchised as power-sharing citizens throughout this era; it is not the political structure of Athens that regresses, but the social status of a beleagured lower peasant class. This has to be emphasized strongly, pace Morris $(1987,8,171,175)$ who conflates "polis origins in the mid 8th century" with the view that "The dependent kakoi of 1050-750 became the citizens of Late Geometric times". 


\section{Bibliographical references}

Auda et al. 1991: AUDA (Y.), DARMEZIN (L.), DECOURT (J.-C.), HELLY (B.), LUCAS (G.), Espace géographique et géographie historique en Thessalie. In: Archéologie et Espaces. $\mathrm{X}^{\mathrm{e}}$ Rencontres Internationales d'Archéologie et d'Histoire (Antibes 1989). Juan-LesPins, 1991, 87-126.

Bailey/Davidson 1983: BAILEY (G. N.), DAVIDSON (I.), Site exploitation territories and topography. JASc, 10, 1983, 87-115.

Berger 1991: BERGER (S.), Great and small poleis in Sicily: Syracuse and Leontinoi. Historia, 40, 1991, 129-142.

Bintliff 1994: BINTLIFF (J. L.), Territorial behaviour and the natural history of the Greek polis. In: Stuttgarter Kolloquium zur Historischen Geographie des Altertums, 4 (Hrsg. E. Olshausen, H. Sonnabend). Amsterdam, 1994, 207-249, Plates 19-73.

Cavanagh 1991: CAVANAGH (W. G.), Surveys, cities and synoecism. In: City and country in the ancient world (J. Rich, A. Wallace-Hadrill eds.). London, 1991, 97-118.

Dunbar 1992: DUNBAR (R.), Why gossip is good for you. New Scientist, 21st November, 1992, 28-31.

Flannery 1976: FLANNERY (K. V.) (ed.), The Early Mesoamerican Village. New York, 1976.

Forge 1972: FORGE (A.), Normative factors in the settlement size of neolithic cultivators (New Guinea). In: Man, settlement and urbanism (P. J. Ucko, G. W. Dimbleby, R. Tringham eds.). London, 1972, 363-376.

Fossey/Morin 1987: FOSSEY (J. M.), MORIN (J.), The Khostia project: excavation and survey. In: Boeotia Antiqua (J. M. Fossey ed.). Amsterdam, 1987, 165-174.

Fox 1981: FOX (H. S. A.), Approaches to the adoption of the Midland system. In: The Origins of Open-Field Agriculture (T. Rowley ed.). London, 1981, 64-111.

Fox 1992: FOX (H. S. A.), The origins of the Midland village. In: Annual Conference of Economic History Society (Precirculated paper). Leicester, 1992.

Freeman 1968: FREEMAN (S. T.), Corporate village organisation in the Sierra Ministra. Man, 3, 1968, 477-484.

Freeman 1970: FREEMAN (S. T.), Neighbours. The Social Contract in a Castilian Hamlet. Chicago, 1970.

Funke 1993: FUNKE (P.), Stamm und Polis. In: Colloquium aus Anlass des 80. Geburtstages von Alfred Heuss (Hrsg. J. Bleicken). Kallmünz, 1993, 29-48, Frankfurter Althistorische Studien (vol. 13).

Garnsey 1988: GARNSEY (P.), Famine and Food Supply in the Graeco-Roman World. Cambridge, 1988.

Gould 1986: GOULD (S. J.), Evolution and the triumph of homology. American Scientist, 74, 1986, 60-69.

Hallam 1981: HALLAM (H. E.), Rural England 10661348. Sussex, 1981.

Hedrick 1991: HEDRICK (C. W. J.), Phratry shrines of Attica and Athens. Hesperia, 60, 1991, 241-268.

Kirsten 1956: KIRSTEN (E.), Die Griechische Polis als historisch-geographisches Problem des Mittelmeerraumes. Bonn, 1956, Colloquium Geographicum 5.

Lewin 1993: LEWIN (R.), Complexity. Life at the Edge of Chaos. London, 1993.

Morris 1987: MORRIS (I.), Burial and Ancient Society. The rise of the Greek city-state. Cambridge, 1987.

Murray 1990: MURRAY (O.), Cities of reason. In: The Greek City from Homer to Alexander (O. Murray, S. Price eds.). Oxford, 1990, 1-25.

Osborne 1985: OSBORNE (R.), Demos: The Discovery of Classical Attika. Cambridge, 1985.

Ridgway 1992: RIDGWAY (D.), The First Western Greeks. Cambridge, 1992.

Ruschenbusch 1985: RUSCHENBUSCH (E.), Die Zahl der griechischen Staaten und Arealgrösse und Bürgerzahl der "Normalpolis". ZPE, 59, 1985, 253263.

Ruschenbusch 1991: RUSCHENBUSCH (E.), Phokis, Lebensraum und Bevölkerungszahl. In: Stuttgarter Kolloquium zur Historischen Geographie des Altertums, 2-3 (Hrsg. E. Olshausen, H. Sonnabend). Bonn, 1991, 299-312.

Sauerwein 1991: SAUERWEIN (F.), Bevölkerungsveränderung und Wirtschaftsstruktur in Boötien in den letzten einhundert Jahren. In: Stuttgarter Kolloquium zur Historischen Geographie des Altertums 2-3 (Hrsg. E. Olshausen, H. Sonnabend). Bonn, 1991, 259-298.

Snodgrass 1990: SNODGRASS (A. M.), Survey archaeology and the rural landscape of the Greek city. In: The Greek City from Homer to Alexander (O. Murray, S. Price eds.). Oxford, 1990, 113-136.

Snodgrass 1991: SNODGRASS (A. M.), Archaeology and the study of the Greek city. In: City and country in the ancient world (J. Rich, A. Wallace-Hadrill eds.). London, 1991, 1-23.

Snodgrass 1993: SNODGRASS (A. M.), The "hoplite reform" revisited. DialHistAnc, 19, 1, 1993, 47-61.

Sourvinou-Inwood 1990: SOURVINOU-INWOOD (C.), What is Polis religion? In: The Greek City from Homer to Alexander (O. Murray, S. Price eds.). Oxford, 1990, 295-322.

Tak 1990: TAK (H.), Longing for local identity: intervillage relations in an Italian town. Anthropological Quarterly, 63, 1990, 90-100.

Whitehead 1986: WHITEHEAD (D.), The Demes of Attica 508/7- ca. 250 B. C. A Political And Social Study. Princeton, 1986.

Whitley 1991: WHITLEY (J.), Social diversity in Dark Age Greece. ABSA, 86, 1991, 341-365.

Wobst 1974: WOBST (H. M.), Boundary conditions for Paleolithic social systems. Am. Ant., 39, 1974, 147178.

Wobst 1976: WOBST (H. M.), Locational relationships in Palaeolithic society. JHE, 5, 1976, 49-58. 